\title{
Helicene synthesis by Brønsted acid-catalyzed cycloaromatization in HFIP $\left[\left(\mathrm{CF}_{3}\right)_{2} \mathrm{CHOH}\right]$
}

\author{
Takeshi Fujita", Noriaki Shoji, Nao Yoshikawa and Junji Ichikawa*
}

\author{
Full Research Paper \\ Address: \\ Division of Chemistry, Faculty of Pure and Applied Sciences, \\ University of Tsukuba, Tsukuba, Ibaraki 305-8571, Japan \\ Email: \\ Takeshi Fujita* - fujita@chem.tsukuba.ac.jp; \\ Junji Ichikawa* - junji@chem.tsukuba.ac.jp \\ * Corresponding author \\ Keywords: \\ acid; catalyst; cyclization; fluoroalcohol; helicenes
}

\author{
Beilstein J. Org. Chem. 2021, 17, 396-403. \\ https://doi.org/10.3762/bjoc.17.35 \\ Received: 28 November 2020 \\ Accepted: 26 January 2021 \\ Published: 09 February 2021 \\ This article is part of the thematic issue "Organo-fluorine chemistry V". \\ Guest Editor: D. O'Hagan \\ (C) 2021 Fujita et al.; licensee Beilstein-Institut. \\ License and terms: see end of document.
}

\begin{abstract}
A facile synthesis of carbo- and heterohelicenes was achieved via tandem cycloaromatization of bisacetal precursors, which were readily prepared through $\mathrm{C}-\mathrm{C}$ bond formation by Suzuki-Miyaura coupling. This cyclization was efficiently realized by a catalytic amount of trifluoromethanesulfonic acid (TfOH) in a cation-stabilizing solvent, 1,1,1,3,3,3-hexafluoropropan-2-ol (HFIP), which readily allowed gram-scale syntheses of higher-order helicenes, double helical helicenes, and heterohelicenes.
\end{abstract}

\section{Introduction}

Helicenes are a class of polycyclic aromatic hydrocarbons (PAH) that consist of ortho-fused aromatic rings arranged in a helical manner [1-6]. Since helicenes possess chirality derived from their helical structure, optically active helicenes and their derivatives exhibit characteristic properties, such as huge optical rotation [7], nonlinear optical effects [8-10], and circularly polarized light emission [11], which are rarely found in planar aromatic hydrocarbons (e.g., acenes and phenacenes). Therefore, the wide breadth of applications of helicenes as organic optical materials make them interesting synthetic targets.

Although several methods for the synthesis of helicenes have been reported, there are still specific problems in conducting these synthetic reactions for large scale production (Scheme 1). For example, the Mallory reaction [12], which is a widely used photocyclization in helicene synthesis $[13,14]$, requires high dilution or excess amounts of oxidizing agents to suppress intermolecular side reactions (Scheme 1a). Diels-Alder (Scheme 1b) [15] and radical reactions (Scheme 1c) [16] directed toward helicene synthesis require high temperature conditions even for low to moderate yields. Olefin metathesis (Scheme 1d) [17] and alkyne trimerization (Scheme 1e) $[18,19]$ require the use of expensive metal catalysts.

Recently, we have developed a Brønsted acid-catalyzed cycloaromatization in 1,1,1,3,3,3-hexafluoropropan-2-ol (HFIP) as solvent [20-22]. Fluoroalcohols, such as HFIP, exhibit high 
(a) Mallory reaction

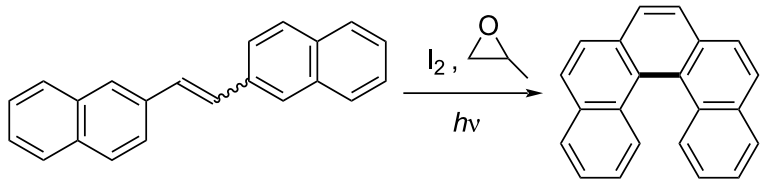

(b) Diels-Alder reaction
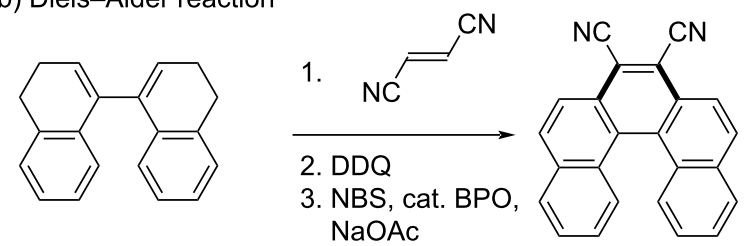

(c) radical reaction
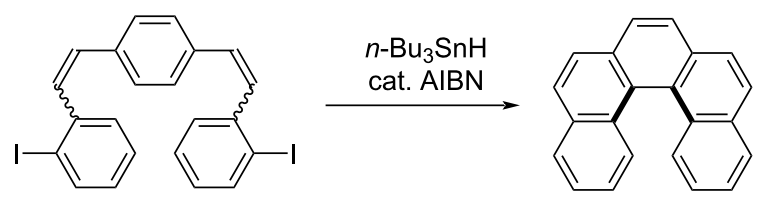

(d) olefin metathesis<smiles>C=Cc1ccc2ccccc2c1-c1c(C=C)ccc2ccc3ccccc3c12</smiles>
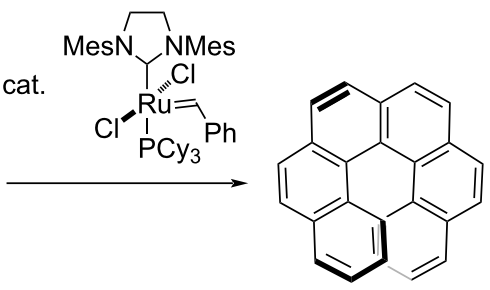

(e) alkyne trimerization
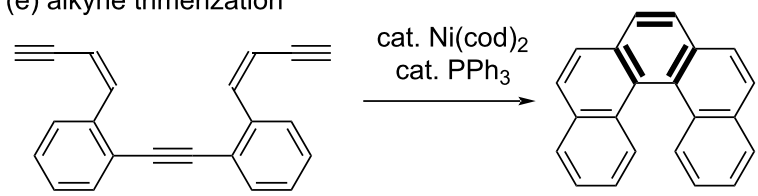

Scheme 1: Conventional methods for the synthesis of helicenes.

ionization power and low nucleophilicity, based on the electronwithdrawing inductive effect of fluorine, which helps to generate cations but does not affect cationic reactions [23-27]. Thus, HFIP greatly facilitates reactions via cationic intermediates [28]. In the presence of a catalytic amount of trifluoromethanesulfonic acid in HFIP, (biaryl-2-yl)acetoaldehydes or their acetal derivatives readily underwent intramolecular Friedel-Crafts-type $\mathrm{C}-\mathrm{C}$ bond formation followed by dehydration or alcohol elimination, leading to the construction of benzene rings in the biaryl systems (Scheme 2) [20,21]. The reaction proceeded via oxocarbenium ion intermediates stabilized by HFIP. This method can be successfully applied to cyclization at multiple reaction sites. By using bisacetals bearing a naphthalene core $\left(\mathrm{Ar}^{2}\right)$ as substrates, tandem cyclization achieved the efficient synthesis of several ortho-fused sixhexagon benzenoids [21].

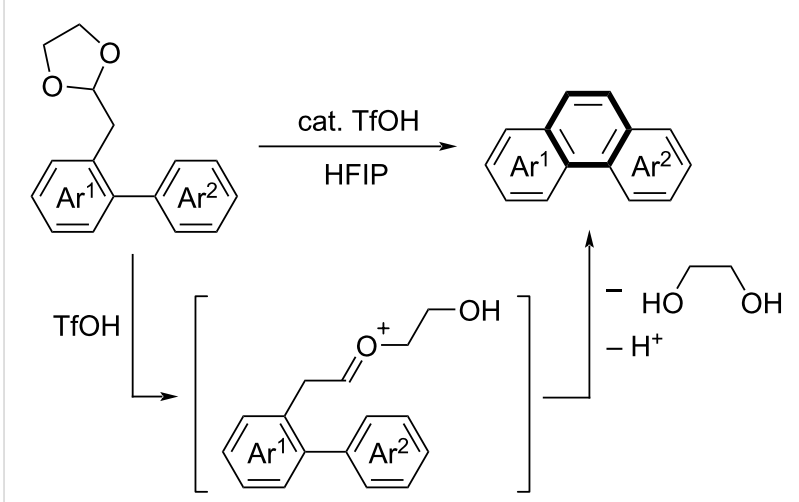

Scheme 2: Brønsted acid-catalyzed cycloaromatization of biaryls bearing an acetal moiety

On the basis of our work mentioned above, we assumed that this powerful cycloaromatization would be applicable to helicene synthesis. Thus, the following strategies were designed to establish a versatile method for the synthesis of helicenes (Scheme 3). Tandem cycloaromatization of bisacetals bearing a teraryl core was shown to be most effective for the one-shot construction of helicene frameworks. Based on ease of preparation, symmetrical cyclization precursors would be preferable, and thus they should possess either (i) one acetal moiety on each terminal aromatic ring $\left(\mathrm{Ar}^{2}\right)$ of the teraryl core (Scheme 3, route a) or (ii) two acetal moieties on the central aromatic ring $\left(\mathrm{Ar}^{1}\right)$ (Scheme 3, route $\mathrm{b}$ ). The teraryl structures were constructed by the formation of two $\mathrm{C}-\mathrm{C}$ bonds via tandem Suzuki-Miyaura coupling of two terminal $\left(\mathrm{Ar}^{2}\right)$ and central $\left(\mathrm{Ar}^{1}\right)$ arenes. It is noted that dihalogenated arenes were adopted as components for the central aromatic ring $\left(\mathrm{Ar}^{1}\right)$ in the teraryl structure, because the diborylated arenes were less available. Either (a) the coupling of boronic acid esters bearing one acetal moiety with dihalogenated arenes or (b) the coupling of dihalogenated arenes bearing two acetal moieties with arylboronic acids were conducted for the preparation of cyclization precursors. As described above, the tandem cycloaromatization of the obtained precursors proceeded via Friedel-Crafts-type bond formation followed by elimination, which enabled a rapid and efficient synthesis of helicenes, such as higher-order helicenes, double helical helicenes, and heterohelicenes.

\section{Results and Discussion}

Carbohelicenes such as [5] helicene (1a) and [6] helicene (1b) were synthesized via Suzuki-Miyaura coupling of readily available dihalogenated arenes $\mathbf{2}$ with phenylboronic acid ester $\mathbf{3}$ bearing a (1,3-dioxolan-2-yl)methyl group [29], followed by triflic acid-catalyzed cycloaromatization (Scheme 3, route a and Scheme 4a). Treatment of 1,2-dibromobenzene (2a) with $\mathbf{3}$ in the presence of a palladium catalyst with SPhos afforded $o$-terphenyl derivative 4 a bearing two acetal groups in $96 \%$ 


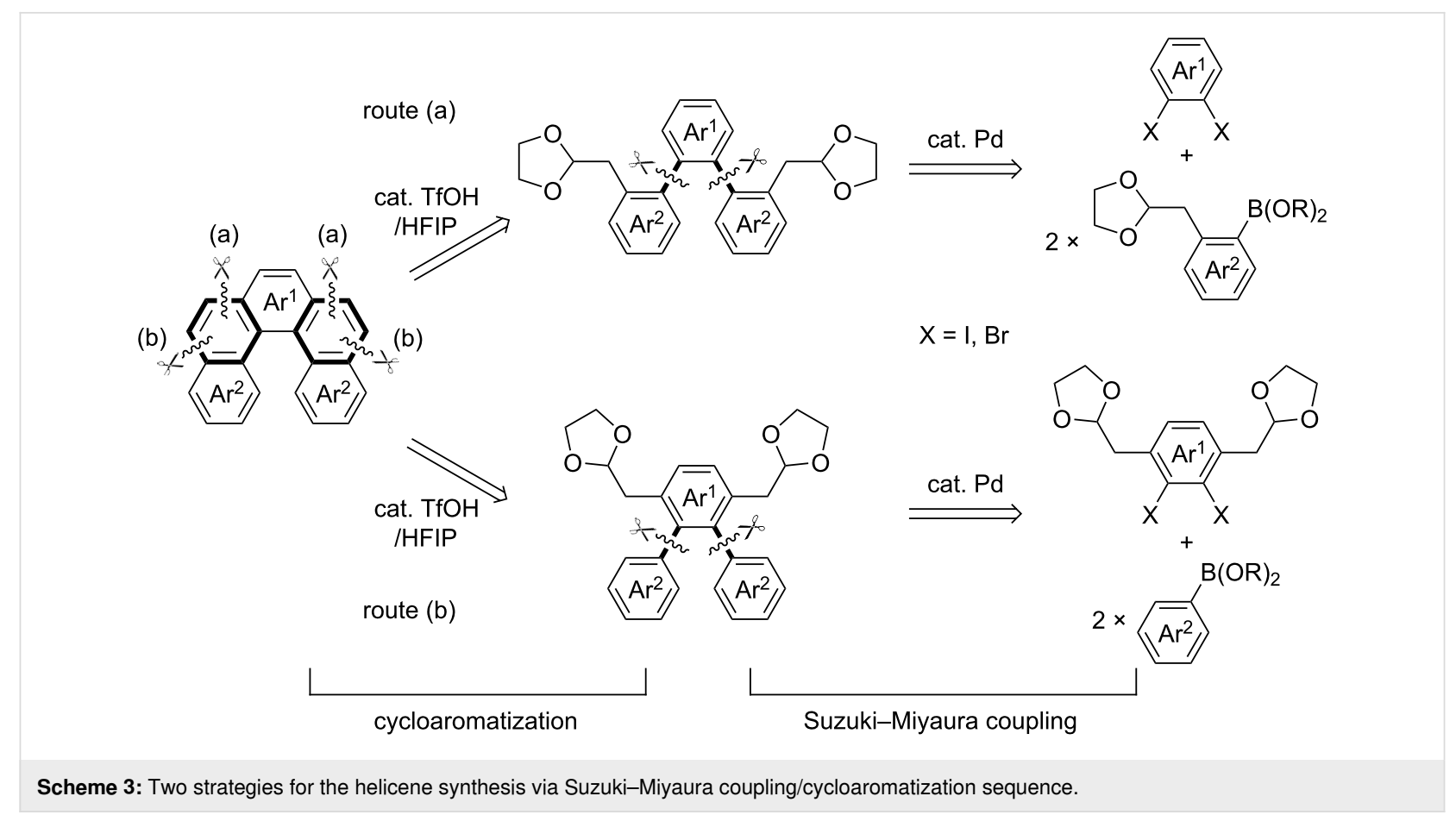

yield (Scheme 4a). The obtained bisacetal 4a successfully underwent cycloaromatization in the presence of $17 \mathrm{~mol} \%$ of TfOH in HFIP to afford [5]helicene (1a) in $90 \%$ yield. For the synthesis of [6]helicene, 1,8-diiodonaphthalene was adopted as the substrate for Suzuki-Miyaura coupling with 3 (Scheme 3 , route a and Scheme $4 \mathrm{~b}$ ). In this coupling, SPhos was also effective in providing the bisacetal precursor $\mathbf{4 b}$ bearing a 1,8diphenylnaphthalene framework in $45 \%$ yield despite high steric hindrance (Scheme 4b). Then, [6]helicene (1b) was obtained in $92 \%$ yield via cycloaromatization in the presence of $15 \mathrm{~mol} \%$ of TfOH. It was noted that the gram-scale synthesis for both [5]- and [6] helicenes was possible, in which no serious decrease in yield was observed in Suzuki-Miyaura coupling and cycloaromatization (see the Experimental section) [30].

Next, double helical compounds were set as synthetic targets, because their unique optical properties have recently attracted much attention [5]. Herein, we synthesized two types of orthofused seven-hexagon benzenoids with two [4] helicene structures. According to the strategy illustrated in Scheme 3, route b, double helical helicenes 5 were synthesized using (naphthyl-1yl)boronic acid (7) and dibromobenzenes 6 with two (1,3dioxolan-2-yl)methyl groups, readily prepared from xylenes (Scheme 5). The Suzuki-Miyaura coupling of dibromobenzene 6a with 7 effectively proceeded to afford bisacetal $\mathbf{8 a}$ in $70 \%$ yield (Scheme 5a). Bisacetal 8a successfully underwent subsequent cycloaromatization in HFIP to afford S-shaped double helical helicene $\mathbf{5 a}$ in $90 \%$ yield. Similarly, C-shaped double helical helicene $\mathbf{5 b}$ was obtained in high yield using $m$-dibromobenzene $\mathbf{6 b}$ with two acetal moieties, prepared from $m$-xylene (Scheme 5b).

We also achieved the synthesis of heterohelicenes, which involve heteroatoms in the helicene frameworks, via a Suzuki-Miyaura coupling/cycloaromatization sequence (Scheme 3a, route a). Thus, hetero[4]-, [5]-, and [6]helicenes involving an oxygen, sulfur, or nitrogen atom were efficiently synthesized (Scheme 6). Hetero[4]helicenes 9 were synthesized via coupling of 3-bromobenzoheteroles 10, prepared from commercially available benzoheteroles, and subsequent cycloaromatization (Scheme 6a). Again, phenylboronic acid ester 3, used above in the synthesis of [5]- and [6]helicenes, was adopted as the coupling partner for $\mathbf{1 0}$. In the presence of a palladium catalyst, treatment of 3-bromobenzofuran (10a), 3-bromobenzothiophene (10b), and 3-bromo( $N$-tosyl)indole (10c) with 3 afforded the corresponding acetals 11a-c with 3-phenylbenzoheterole structures in $92 \%, 80 \%$, and $93 \%$ yields, respectively. Acetals 11a-c successfully underwent $\mathrm{TfOH}$-catalyzed cycloaromatization in HFIP to afford oxa-, thia-, and aza[4]helicenes 9a-c in $96 \%, 88 \%$, and $93 \%$ yields, respectively. Thus, phenylboronic acid ester $\mathbf{3}$ bearing an acetal moiety functions as a reagent for fused naphthalene ring extension through our cross-coupling/ cycloaromatization sequence [31-35].

Hetero[5]helicenes $\mathbf{1 2}$ were synthesized via tandem cycloaromatization using teraryl precursors, in which heterol rings were set as central aromatic rings $\left(\mathrm{Ar}^{1}\right)$ (Scheme 3 , route a and Scheme $6 b$ ). As in the original strategy (Scheme 3, route a), 
(a)

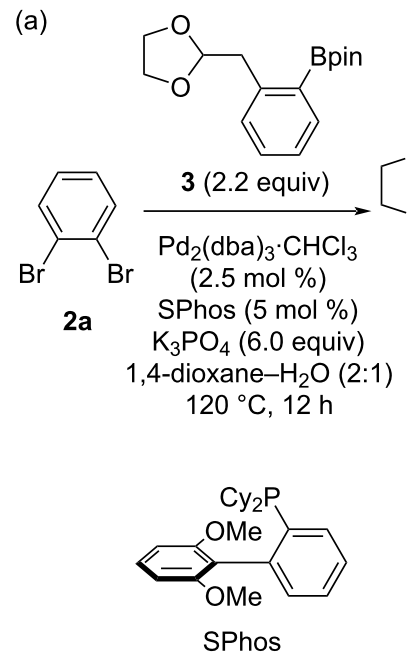

(b)

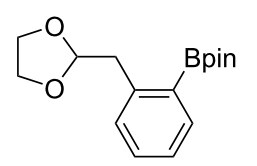<smiles>Ic1cccc2cccc(I)c12</smiles>

2b

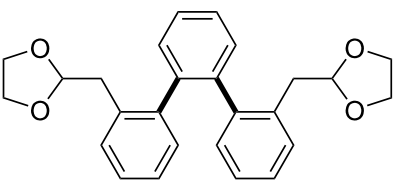

4a $96 \%$

$(86 \%, 2.16 \mathrm{~g}$ from

$1.47 \mathrm{~g}$ of $\mathbf{2 a})$
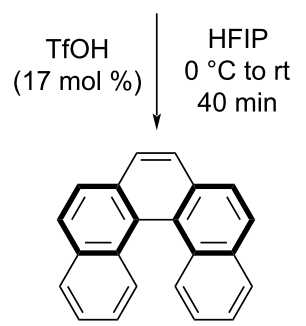

1a $90 \%$

$(80 \%, 1.19 \mathrm{~g})$

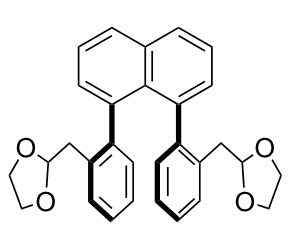

4b $45 \%$

$(40 \%, 2.05 \mathrm{~g}$ from $4.35 \mathrm{~g}$ of $\mathbf{2 b}$ )
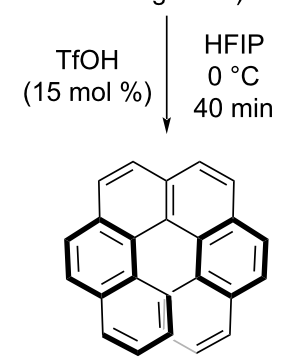

1b $92 \%$

$(88 \%, 1.31 \mathrm{~g})$

coupling of 3,4-dibromofuran (13a), 3,4-dibromothiophene (13b), and 3,4-dibromo( $N$-tosyl)pyrrole (13c) with phenylboronic acid ester $\mathbf{3}$ bearing an acetal moiety proceeded to afford the corresponding bisacetals $14 a-\mathbf{c}$ in $53 \%, 76 \%$, and $78 \%$ yields, respectively. The obtained bisacetals $14 a-c$ efficiently underwent $\mathrm{TfOH}$-catalyzed tandem cycloaromatization under appropriate conditions to afford oxa-, thia-, and aza[5]helicenes 12a-c in $90 \%, 90 \%$, and $88 \%$ yields, respectively.
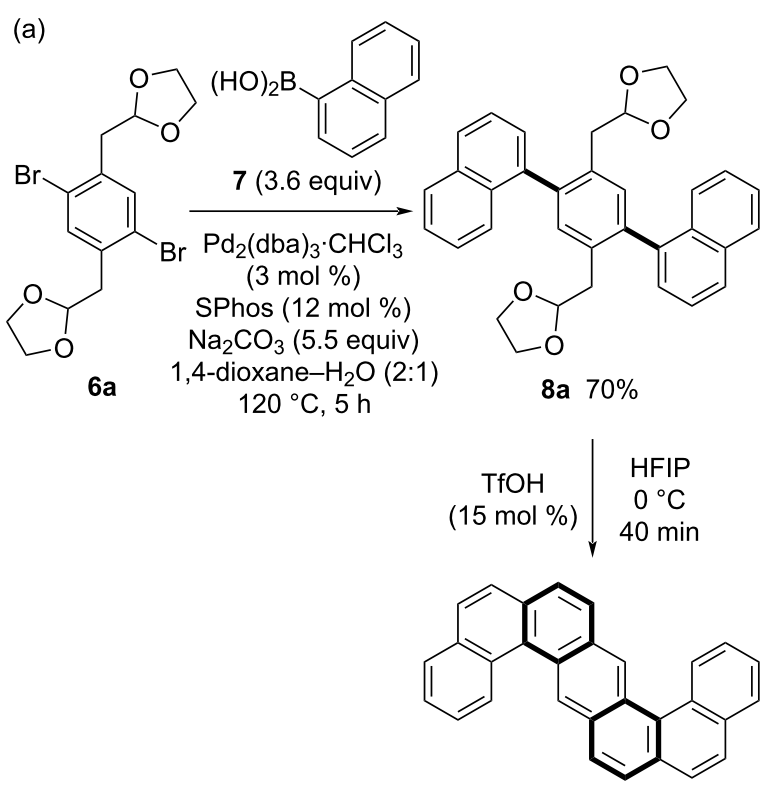

5a $90 \%$

(b)

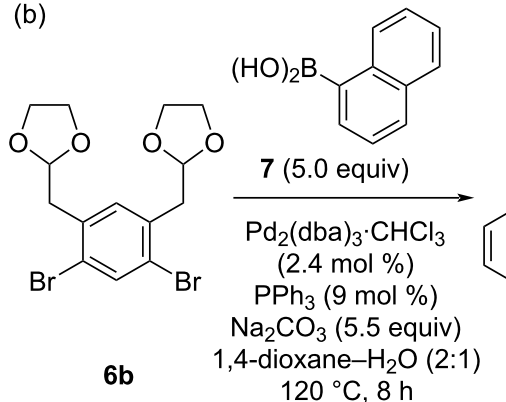<smiles>c1ccc2c(-c3cc(-c4cccc5ccccc45)c(CC4OCCO4)cc3CC3OCCO3)cccc2c1</smiles>

8b $86 \%$

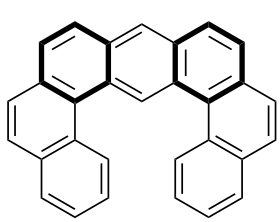

5b $86 \%$

Scheme 5: Synthesis of helicenes with double helical structures.

Furthermore, we demonstrated the synthesis of unsymmetrical thia[6] helicene $\mathbf{1 5}$ as a hetero[6]helicene synthesis (Scheme 6c). 3-Bromobenzothiophene 16 bearing a (1,3-dioxolan-2yl)methyl group at the 2-position, which was readily prepared from benzothiophene, underwent Suzuki-Miyaura coupling with boronic acid ester 17 with a biphenyl structure and an acetal moiety, to afford bisacetal $\mathbf{1 8}$ in $92 \%$ yield. Thus, tandem cycloaromatization of $\mathbf{1 8}$ effectively proceeded to afford thia[6]helicene $\mathbf{1 5}$ in $63 \%$ yield. 
(a)

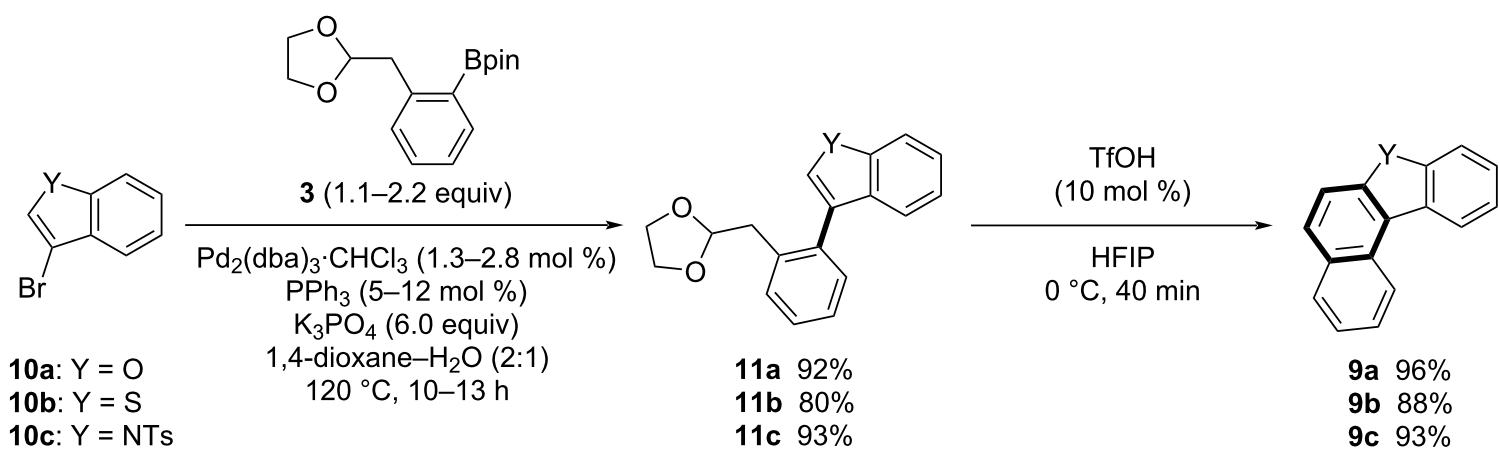

(b)

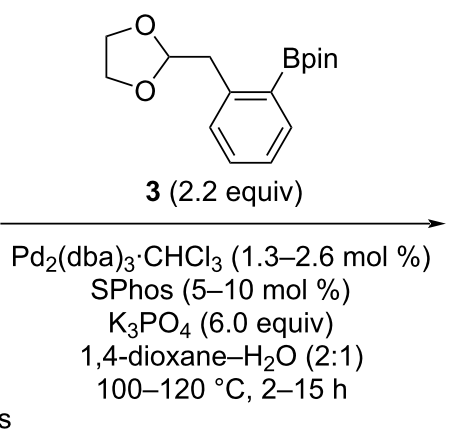

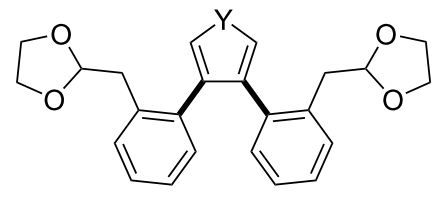

14a $53 \%$

14b $76 \%$

14c $78 \%$
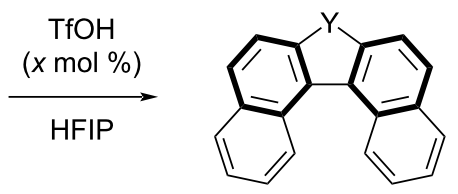

12a $90 \%\left(x=18,0^{\circ} \mathrm{C}\right.$ to $\left.\mathrm{rt}, 40 \mathrm{~min}\right)$

12b $90 \%\left(x=11,0^{\circ} \mathrm{C}, 40 \mathrm{~min}\right)$

12c $88 \%\left(x=15,0^{\circ} \mathrm{C}\right.$ to $\left.\mathrm{rt}, 40 \mathrm{~min}\right)$<smiles>Brc1c(CC2OCCO2)sc2ccccc12</smiles>

16<smiles>Oc1ccccc1-c1ccccc1CC1OCCO1</smiles>

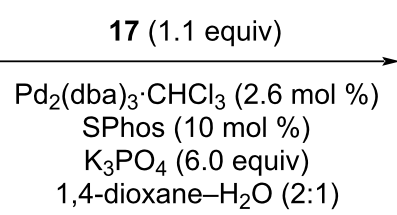
$120^{\circ} \mathrm{C}, 9 \mathrm{~h}$

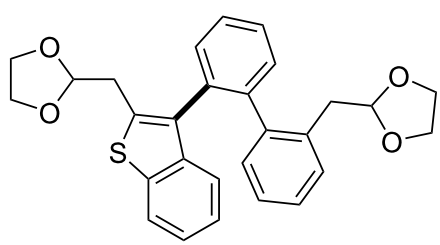

$1892 \%$

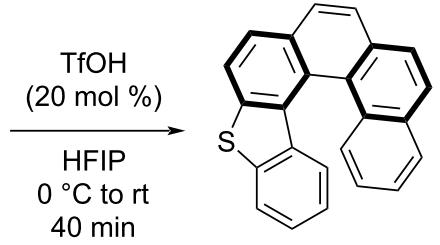

$1563 \%$

Scheme 6: Synthesis of hetero[4]-, [5]-, and [6]helicenes.

\section{Conclusion}

In summary, we developed a facile and efficient method for the synthesis of several types of helicenes using a sequence of (i) Suzuki-Miyaura coupling of acetal-containing components and (ii) catalytic cycloaromatization with the aid of a cation-stabilizing fluoroalcohol, HFIP, as solvent. Particularly, helicene synthesis using tandem cyclization of bisacetals with teraryl structures is suitable for mass production of helicenes not only because multiple aromatic rings can be constructed at the same time but also because precursors can be easily prepared from commercially available compounds. Therefore, further progress can be made in applied research on helicenes as organic electronic materials, such as circularly polarized light emitting devices and nonlinear optical materials [7-11].

\section{Experimental}

${ }^{1} \mathrm{H}$ NMR and ${ }^{13} \mathrm{C}$ NMR spectra were recorded on a Bruker Avance 500 or a JEOL ECS-400 spectrometer. Chemical shift values are given in ppm relative to internal $\mathrm{Me}_{4} \mathrm{Si}$ (for ${ }^{1} \mathrm{H}$ NMR: $\delta=0.00 \mathrm{ppm}$ ) and $\mathrm{CDCl}_{3}$ (for ${ }^{13} \mathrm{C} \mathrm{NMR}$ : $\delta=77.0 \mathrm{ppm})$.

Column chromatography and preparative thin-layer chromatography (PTLC) were conducted on silica gel (Silica Gel $60 \mathrm{~N}$, Kanto Chemical Co., Inc. for column chromatography and Wakogel B-5F, Wako Pure Chemical Inductries for PTLC). $N, N$-Dimethylformamide (DMF) was purified by a solventpurification system (GlassContour) equipped with columns of activated alumina and supported-copper catalyst (Q-5) before use. 1,1,1,3,3,3-Hexafluoropropan-2-ol (HFIP) was distilled 
from molecular sieves $4 \AA$ and stored over activated molecular sieves 4 A. 1,4-Dioxane was distilled from sodium and stored over activated molecular sieves $4 \AA$. $2-\{2-[(1,3-D i o x o l a n-2-$ yl)methyl]phenyl \}-4,4,5,5-tetramethyl-1,3,2-dioxaborolane (3) was prepared according to the literature procedure, and their spectral data showed good agreement with the literature data [21]. Unless otherwise noted, materials were obtained from commercial sources and used directly without further purification.

\section{2,2"-Bis[(1,3-dioxolan-2-yl)methyl]-1,1':2',1"- terphenyl (4a)}

A dioxane $(6.6 \mathrm{~mL})$ and $\mathrm{H}_{2} \mathrm{O}(3.4 \mathrm{~mL})$ solution of 1,2-dibromobenzene (2a, $471 \mathrm{mg}, 2.00 \mathrm{mmol})$, boronate ester $\mathbf{3}(1.27 \mathrm{~g}$, $4.39 \mathrm{mmol}), \mathrm{Pd}_{2}(\mathrm{dba})_{3} \cdot \mathrm{CHCl}_{3}(52 \mathrm{mg}, 51 \mu \mathrm{mol})$, SPhos (41 mg, $0.10 \mathrm{mmol})$, and $\mathrm{K}_{3} \mathrm{PO}_{4}(2.53 \mathrm{~g}, 11.9 \mathrm{mmol})$ was degassed by using the freeze-pump-thaw method three times. After stirring at $120{ }^{\circ} \mathrm{C}$ for $12 \mathrm{~h}$, ethyl acetate and water were added to the mixture, and organic materials were extracted with ethyl acetate three times. The combined extracts were washed with brine and dried over $\mathrm{Na}_{2} \mathrm{SO}_{4}$. After removal of the solvent under reduced pressure, the residue was purified by silica gel column chromatography (hexane/EtOAc $=3: 1)$ to give $4 \mathbf{a}(776 \mathrm{mg}, 96 \%)$ as an orange oil.

${ }^{1} \mathrm{H}$ NMR $\left(500 \mathrm{MHz}, \mathrm{CDCl}_{3}\right) \delta 2.59(\mathrm{dd}, J=14.4,4.9 \mathrm{~Hz}$, $0.8 \mathrm{H}), 2.70(\mathrm{dd}, J=14.3,5.3 \mathrm{~Hz}, 1.2 \mathrm{H}), 2.78-2.86(\mathrm{~m}, 2 \mathrm{H})$, 3.72-3.95 (m, 8H), 4.85-4.95 (m, 2H), 6.97-7.03 (m, 4H), 7.07-7.14 (m, 2H), 7.23-7.33 (m, 3.2H), 7.35-7.42 (m, 2.8H); ${ }^{13} \mathrm{C}$ NMR $\left(126 \mathrm{MHz}, \mathrm{CDCl}_{3}\right) \delta 37.1,37.7,64.6,64.73,64.75$, 104.5, 104.6, 125.4, 125.7, 126.8, 126.87, 126.91, 126.0, 129.5, 129.6, 130.0, 130.7, 131.2, 131.6, 133.8, 134.0, 140.2, 140.9, 141.4; IR (neat) v: 3055, 3020, 2976, 2883, 1471, 1442, 1433, 1398, 1194, 1130, 1038, 1009, 943, 872, 837, 822, 752, 706, $621,573,538 \mathrm{~cm}^{-1}$; HRMS (EI) $\mathrm{m} / \mathrm{z}:[\mathrm{M}]^{+}$calcd. for $\mathrm{C}_{26} \mathrm{H}_{26} \mathrm{O}_{4}$, 402.1826; found, 402.1815 .

Gram-scale synthesis: Compound $4 \mathbf{a}$ was also prepared by the method described above using 1,2-dibromobenzene (2a, $1.47 \mathrm{~g}$, $6.24 \mathrm{mmol})$, boronate ester 3 (3.99 g, $13.8 \mathrm{mmol})$, $\mathrm{Pd}_{2}(\mathrm{dba})_{3} \cdot \mathrm{CHCl}_{3}(82 \mathrm{mg}, 80 \mu \mathrm{mol}), \mathrm{PPh}_{3}(84 \mathrm{mg}, 0.32 \mathrm{mmol})$, $\mathrm{K}_{3} \mathrm{PO}_{4}(8.02 \mathrm{~g}$, $37.8 \mathrm{mmol})$, dioxane $(21 \mathrm{~mL})$, and $\mathrm{H}_{2} \mathrm{O}$ $(10 \mathrm{~mL})$ at $100{ }^{\circ} \mathrm{C}$ for $6 \mathrm{~h}$. Purification by silica gel column chromatography (hexane/EtOAc $=5: 1)$ gave $4 \mathbf{a}(2.16 \mathrm{~g}, 86 \%)$.

\section{[5]Helicene (1a)}

In a similar manner as described in [20], trifluoromethanesulfonic acid $(7.5 \mathrm{mg}, 50 \mu \mathrm{mol})$ was added to an $\operatorname{HFIP}(0.9 \mathrm{~mL})$ solution of bisacetal $4 \mathbf{a}(120 \mathrm{mg}, 0.30 \mathrm{mmol})$ at $0{ }^{\circ} \mathrm{C}$. After stirring at room temperature for $40 \mathrm{~min}$, the reaction was quenched with phosphate buffer ( $\mathrm{pH} 7$ ). Organic materials were extracted with $\mathrm{CH}_{2} \mathrm{Cl}_{2}$ three times, and the combined extracts were washed with brine and dried over $\mathrm{Na}_{2} \mathrm{SO}_{4}$. After removal of the solvents under reduced pressure, the residue was purified by silica gel column chromatography (hexane $/ \mathrm{CH}_{2} \mathrm{Cl}_{2}=3: 1$ ) to give $1 \mathbf{a}(75 \mathrm{mg}, 90 \%)$ as a white solid.

${ }^{1} \mathrm{H}$ NMR $\left(500 \mathrm{MHz}, \mathrm{CDCl}_{3}\right) \delta 7.23(\mathrm{dd}, J=8.4,7.1 \mathrm{~Hz}, 2 \mathrm{H})$, $7.47(\mathrm{dd}, J=7.9,7.1 \mathrm{~Hz}, 2 \mathrm{H}), 7.80(\mathrm{~s}, 2 \mathrm{H}), 7.81(\mathrm{~d}, J=8.5 \mathrm{~Hz}$, $2 \mathrm{H}), 7.86(\mathrm{~d}, J=8.5 \mathrm{~Hz}, 2 \mathrm{H}), 7.90(\mathrm{~d}, J=7.9 \mathrm{~Hz}, 2 \mathrm{H}), 8.49$ (d, $J=8.4 \mathrm{~Hz}, 2 \mathrm{H}) ;{ }^{13} \mathrm{C} \mathrm{NMR}\left(126 \mathrm{MHz}, \mathrm{CDCl}_{3}\right) \delta 124.3,126.2$, 126.3, 126.9, 127.2, 127.4, 127.8, 129.0, 130.7, 132.2, 132.5.

Gram-scale synthesis: Compound 1a was also synthesized by the method described above using bisacetal 4a (2.16 g, $5.37 \mathrm{mmol})$, trifluoromethanesulfonic acid $(88 \mathrm{mg}, 0.58 \mathrm{mmol})$, and HFIP $(20 \mathrm{~mL})$ at $0{ }^{\circ} \mathrm{C}$ for $40 \mathrm{~min}$. Purification by silica gel column chromatography (hexane/EtOAc $=10: 1$ ) gave $\mathbf{1 a}$ $(1.19 \mathrm{~g}, 80 \%)$.

\section{1,8-Bis $\{2-[(1,3-$ dioxolan-2- yl)methyl]phenyl\}naphthalene (4b)}

A DMF $(6.7 \mathrm{~mL})$ and $\mathrm{H}_{2} \mathrm{O}(3.3 \mathrm{~mL})$ solution of 1,8-diiodonaphthalene (2b, $759 \mathrm{mg}, 2.00 \mathrm{mmol})$, boronate ester $\mathbf{3}$ (1.28 g, $4.40 \mathrm{mmol}), \mathrm{Pd}_{2}(\mathrm{dba})_{3} \cdot \mathrm{CHCl}_{3}(52 \mathrm{mg}, 50 \mu \mathrm{mol})$, SPhos (42 mg, $0.10 \mathrm{mmol})$, and $\mathrm{K}_{3} \mathrm{PO}_{4}(2.54 \mathrm{~g}, 12.0 \mathrm{mmol})$ was degassed by using the freeze-pump-thaw method three times. After stirring at $90{ }^{\circ} \mathrm{C}$ for $10 \mathrm{~h}$, ethyl acetate, hexane, and water were added to the mixture, and organic materials were extracted with an ethyl acetate-hexane (1:1) mixed solvent three times. The combined extracts were washed with brine and dried over $\mathrm{Na}_{2} \mathrm{SO}_{4}$. After removal of the solvent under reduced pressure, the residue was purified by silica gel column chromatography (toluene/EtOAc $=40: 1)$ to give $\mathbf{4 b}(409 \mathrm{mg}, 45 \%)$ as a white solid.

${ }^{1} \mathrm{H}$ NMR $\left(500 \mathrm{MHz}, \mathrm{CDCl}_{3}\right) \delta 2.36(\mathrm{dd}, J=14.0,6.1 \mathrm{~Hz}, 2 \mathrm{H})$, $2.52(\mathrm{dd}, J=14.0,4.3 \mathrm{~Hz}, 2 \mathrm{H}), 3.62-3.83(\mathrm{~m}, 8 \mathrm{H}), 4.65(\mathrm{dd}$, $J=6.1,4.3 \mathrm{~Hz}, 2 \mathrm{H}), 6.77-6.81(\mathrm{~m}, 2 \mathrm{H}), 6.87-6.93(\mathrm{~m}, 4 \mathrm{H})$, $7.01-7.06(\mathrm{~m}, 2 \mathrm{H}), 7.20(\mathrm{dd}, J=7.0,1.3 \mathrm{~Hz}, 2 \mathrm{H}), 7.46(\mathrm{dd}, J=$ $8.1,7.0 \mathrm{~Hz}, 2 \mathrm{H}), 7.91(\mathrm{dd}, J=8.3,1.3 \mathrm{~Hz}, 2 \mathrm{H}) ;{ }^{13} \mathrm{C} \mathrm{NMR}$ $\left(126 \mathrm{MHz}, \mathrm{CDCl}_{3}\right) \delta 38.9,64.4,64.7,104.1,124.8,125.2$, 126.8, 129.0, 129.05, 129.13, 129.9, 131.0, 133.8, 134.5, 138.8, 142.6; IR (neat) v: 3053, 2966, 2883, 1489, 1396, 1132, 1043, 984, 831, $756 \mathrm{~cm}^{-1}$; HRMS (APCI+) $\mathrm{m} / \mathrm{z}:[\mathrm{M}+\mathrm{H}]^{+}$calcd. for $\mathrm{C}_{30} \mathrm{H}_{29} \mathrm{O}_{4}$, 453.2060; found, 453.2081.

Gram-scale synthesis: Compound $\mathbf{4 b}$ was also prepared by the method described above using 1,8-diiodonaphthalene (2b, $4.35 \mathrm{~g}, 11.4 \mathrm{mmol})$, boronate ester $3(7.31 \mathrm{~g}, 25.2 \mathrm{mmol})$, $\mathrm{Pd}_{2}(\mathrm{dba})_{3} \cdot \mathrm{CHCl}_{3}(301 \mathrm{mg}, 0.29 \mathrm{mmol})$, SPhos (239 mg, $0.58 \mathrm{mmol}), \mathrm{K}_{3} \mathrm{PO}_{4}(14.6 \mathrm{~g}, 68.7 \mathrm{mmol}), \mathrm{DMF}(38 \mathrm{~mL})$, and 
$\mathrm{H}_{2} \mathrm{O}(19 \mathrm{~mL})$ at $90{ }^{\circ} \mathrm{C}$ for $17 \mathrm{~h}$. Purification by silica gel column chromatography (toluene/EtOAc $=40: 1$ ) gave $\mathbf{4 b}$ (2.05 g, 40\%).

\section{[6]Helicene (1b)}

In a similar manner as described in [20]. To an HFIP $(0.7 \mathrm{~mL})$ solution of bisacetal $\mathbf{4 b}(91 \mathrm{mg}, 0.20 \mathrm{mmol})$ was added trifluoromethanesulfonic acid $(4.8 \mathrm{mg}, 32 \mu \mathrm{mol})$ at $0{ }^{\circ} \mathrm{C}$. After stirring at the same temperature for $40 \mathrm{~min}$, the reaction was quenched with phosphate buffer ( $\mathrm{pH} 7$ ). Organic materials were extracted with ethyl acetate three times, and the combined extracts were washed with brine and dried over $\mathrm{Na}_{2} \mathrm{SO}_{4}$. After removal of the solvents under reduced pressure, the residue was purified by silica gel column chromatography (hexane $/ \mathrm{CH}_{2} \mathrm{Cl}_{2}$ $=3: 1)$ to give $\mathbf{1 b}(60 \mathrm{mg}, 92 \%)$ as a yellow solid.

${ }^{1} \mathrm{H}$ NMR $\left(500 \mathrm{MHz}, \mathrm{CDCl}_{3}\right) \delta 6.66(\mathrm{dd}, J=8.5,7.4 \mathrm{~Hz}, 2 \mathrm{H})$, $7.19(\mathrm{dd}, J=7.9,7.4 \mathrm{~Hz}, 2 \mathrm{H}), 7.58(\mathrm{~d}, J=8.5 \mathrm{~Hz}, 2 \mathrm{H}), 7.80$ (d, $J=7.9 \mathrm{~Hz}, 2 \mathrm{H}), 7.89(\mathrm{~s}, 4 \mathrm{H}), 7.93(\mathrm{~d}, J=8.1 \mathrm{~Hz}, 2 \mathrm{H}), 7.96(\mathrm{~d}$, $J=8.1 \mathrm{~Hz}, 2 \mathrm{H}) ;{ }^{13} \mathrm{C} \mathrm{NMR}\left(126 \mathrm{MHz}, \mathrm{CDCl}_{3}\right) \delta 124.0,124.6$, $125.5,126.1,126.8,127.2,127.5,127.7,127.8,128.0,129.9$, $131.2,131.7,133.1$.

Gram-scale synthesis: Compound $1 \mathrm{~b}$ was also synthesized by the method described above using bisacetal $4 \mathbf{b}$ (2.05 g, $4.53 \mathrm{mmol})$, trifluoromethanesulfonic acid (173 mg, $1.2 \mathrm{mmol})$, and HFIP $(15 \mathrm{~mL})$ at $0{ }^{\circ} \mathrm{C}$ for $3 \mathrm{~h}$. Purification by silica gel column chromatography (hexane $/ \mathrm{CH}_{2} \mathrm{Cl}_{2}=3: 1$ ) gave $\mathbf{1 b}$ $(1.31 \mathrm{~g}, 88 \%)$.

\section{Supporting Information}

\section{Supporting Information File 1}

Detailed experimental procedures and spectral data. [https://www.beilstein-journals.org/bjoc/content/ supplementary/1860-5397-17-35-S1.pdf]

\section{Acknowledgements}

We acknowledge Central Glass Co., Ltd. for generous gifts of 1,1,1,3,3,3-hexafluoropropan-2-ol (HFIP) and trifluoromethanesulfonic acid (TfOH). We thank Mr. M. Hayashi for initial investigation of this work.

\section{Funding}

This work was financially supported by JSPS KAKENHI Grant Number JP19H02707 (J.I.) in Grant-in-Aid for Scientific Research (B), JSPS KAKENHI Grant Number JP18H04234 (J.I.) in Precisely Designed Catalysts with Customized Scaffolding, JSPS KAKENHI Grant Number JP20K21186 (J.I.) in
Grant-in-Aid for Challenging Research (Exploratory), and JSPS KAKENHI Grant Number JP18K05116 (T.F.) in Grant-in-Aid for Scientific Research (C).

\section{ORCID ${ }^{\circledR}$ iDs}

Takeshi Fujita - https://orcid.org/0000-0001-9666-022X

Junji Ichikawa - https://orcid.org/0000-0001-6498-326X

\section{References}

1. Shen, Y.; Chen, C.-F. Chem. Rev. 2012, 112, 1463-1535. doi:10.1021/cr200087r

2. Gingras, M. Chem. Soc. Rev. 2013, 42, 968-1006. doi:10.1039/c2cs35154d

3. Gingras, M.; Félix, G.; Peresutti, R. Chem. Soc. Rev. 2013, 42, 1007-1050. doi:10.1039/c2cs35111k

4. Gingras, M. Chem. Soc. Rev. 2013, 42, 1051-1095. doi:10.1039/c2cs35134j

5. Li, C.; Yang, Y.; Miao, Q. Chem. - Asian J. 2018, 13, 884-894. doi:10.1002/asia.201800073

6. Dhbaibi, K.; Favereau, L.; Crassous, J. Chem. Rev. 2019, 119, 8846-8953. doi:10.1021/acs.chemrev.9b00033

7. Newman, M. S.; Lutz, W. B.; Lednicer, D. J. Am. Chem. Soc. 1955, 77, 3420-3421. doi:10.1021/ja01617a097

8. Verbiest, T.; Van Elshocht, S.; Kauranen, M.; Hellemans, L.; Snauwaert, J.; Nuckolls, C.; Katz, T. J.; Persoons, A. Science 1998, 282, 913-915. doi:10.1126/science.282.5390.913

9. Verbiest, T.; Van Elshocht, S.; Persoons, A.; Nuckolls, C.; Phillips, K. E.; Katz, T. J. Langmuir 2001, 17, 4685-4687. doi:10.1021/la010262u

10. Clays, K.; Wostyn, K.; Persoons, A.; Maiorana, S.; Papagni, A.; Daul, C. A.; Weber, V. Chem. Phys. Lett. 2003, 372, 438-442. doi:10.1016/s0009-2614(03)00437-8

11. Zhao, W.-L.; Li, M.; Lu, H.-Y.; Chen, C.-F. Chem. Commun. 2019, 55, 13793-13803. doi:10.1039/c9cc06861a and references cited therein.

12. Mallory, F. B.; Mallory, C. W. Org. React. 1984, 30, 1-456. doi:10.1002/0471264180.or030.01

13. Flammang-Barbieux, M.; Nasielski, J.; Martin, R. H. Tetrahedron Lett. 1967, 8, 743-744. doi:10.1016/s0040-4039(00)90586-0

14. Mori, K.; Murase, T.; Fujita, M. Angew. Chem., Int. Ed. 2015, 54, 6847-6851. doi:10.1002/anie.201502436

15. Mandal, B. K.; Sooksimuang, T. J. Porphyrins Phthalocyanines 2002, 6, 66-72. doi:10.1142/s1088424602000105

16. Harrowven, D. C.; Nunn, M. I. T.; Fenwick, D. R. Tetrahedron Lett. 2002, 43, 7345-7347. doi:10.1016/s0040-4039(02)01720-3

17. Collins, S. K.; Grandbois, A.; Vachon, M. P.; Côté, J. Angew. Chem., Int. Ed. 2006, 45, 2923-2926. doi:10.1002/anie.200504150

18. Teplý, F.; Stará, I. G.; Starý, I.; Kollárovič, A.; Šaman, D.; Rulíšek, L.; Fiedler, P. J. Am. Chem. Soc. 2002, 124, 9175-9180. doi:10.1021/ja0259584

19. Hosokawa, T.; Takahashi, Y.; Matsushima, T.; Watanabe, S.; Kikkawa, S.; Azumaya, I.; Tsurusaki, A.; Kamikawa, K. J. Am. Chem. Soc. 2017, 139, 18512-18521. doi:10.1021/jacs.7b07113

20. Fujita, T.; Takahashi, I.; Hayashi, M.; Wang, J.; Fuchibe, K.; Ichikawa, J. Eur. J. Org. Chem. 2017, 262-265. doi:10.1002/ejoc.201601406 
21. Takahashi, I.; Hayashi, M.; Fujita, T.; Ichikawa, J. Chem. Lett. 2017, 46, 392-394. doi:10.1246/cl.161122

22. Takahashi, I.; Fujita, T.; Shoji, N.; Ichikawa, J. Chem. Commun. 2019, 55, 9267-9270. doi:10.1039/c9cc04152d

23. Bégué, J.-P.; Bonnet-Delpon, D.; Crousse, B. Synlett 2004, 18-29. doi:10.1055/s-2003-44973

24. Shuklov, I. A.; Dubrovina, N. V.; Börner, A. Synthesis 2007, 2925-2943. doi:10.1055/s-2007-983902

25. Dohi, T.; Yamaoka, N.; Kita, Y. Tetrahedron 2010, 66, 5775-5785. doi:10.1016/j.tet.2010.04.116

26. Khaksar, S. J. Fluorine Chem. 2015, 172, 51-61. doi:10.1016/j.jluchem.2015.01.008

27. Colomer, I.; Chamberlain, A. E. R.; Haughey, M. B.; Donohoe, T. J. Nat. Rev. Chem. 2017, 1, No. 88. doi:10.1038/s41570-017-0088

28. Ichikawa, J.; Miyazaki, S.; Fujiwara, M.; Minami, T. J. Org. Chem. 1995, 60, 2320-2321. doi:10.1021/j000113a005

29. The corresoponding boronic acid was also applicable to the preparation of $\mathbf{4 a}$.

30. In the gram-scale preparation of $\mathbf{4 a}, \mathrm{PPh}_{3}$ was used instead of SPhos (see the Experimental section).

31. Bowles, D. M.; Anthony, J. E. Org. Lett. 2000, 2, 85-87. doi:10.1021/ol991254w

32. Komeyama, K.; Okamoto, Y.; Takaki, K. Angew. Chem., Int. Ed. 2014, 53, 11325-11328. doi:10.1002/anie.201406807

33. Zhang, K.; Cai, L.; Jiang, X.; Garcia-Garibay, M. A.; Kwon, O. J. Am. Chem. Soc. 2015, 137, 11258-11261. doi:10.1021/jacs.5b07403

34. Fuchibe, K.; Imaoka, H.; Ichikawa, J. Chem. - Asian J. 2017, 12, 2359-2363. doi:10.1002/asia.201700870

35. Murai, M.; Ogita, T.; Takai, K. Chem. Commun. 2019, 55, 2332-2335. doi: $10.1039 / \mathrm{c} 9 \mathrm{cc} 00270 \mathrm{~g}$

\section{License and Terms}

This is an Open Access article under the terms of the Creative Commons Attribution License (https://creativecommons.org/licenses/by/4.0). Please note that the reuse, redistribution and reproduction in particular requires that the author(s) and source are credited and that individual graphics may be subject to special legal provisions.

The license is subject to the Beilstein Journal of Organic Chemistry terms and conditions:

(https://www.beilstein-journals.org/bjoc/terms)

The definitive version of this article is the electronic one which can be found at: https://doi.org/10.3762/bjoc.17.35 